\title{
The Impact of Using Story Maps as Graphic Organizers on Development of Vocabulary Learning of EFL Learners
}

\author{
Mohammad Khatib \\ Allameh Tabataba'i University, Tehran, Iran \\ Email: mkhatib27@yahoo.com \\ Laleh Fakhraee Faruji \\ Department of Humanities, Shahr-e- Qods Branch, Islamic Azad University, Tehran, Iran \\ Email: fakhraeelaleh@yahoo.com
}

\begin{abstract}
The present study has been an attempt to investigate the impact of using story maps as graphic organizers on developing vocabulary learning of Iranian intermediate EFL learners. Sixty male and female students, who had scored homogenously in a TOEFL test, participated in this study. Both the control and the experimental groups participated in a vocabulary pre-test. After undergoing a course of 8 sessions of reading short stories, through which story maps were used as post-reading activity in the experimental group and traditional question and answer techniques were used in the control group, both groups took part in a vocabulary post-test. The data analysis revealed a significant difference between the performances of the two groups with the experimental group outperforming the other.
\end{abstract}

Index Terms — graphic organizers, incidental vocabulary learning, plot, story maps, theme

\section{INTRODUCTION}

For a long time, literature has not been included in the curriculum of teaching English, since teaching a foreign language has been regarded as a matter of linguistics (Eren, 2004). "In sixties and seventies, in fact, there was a distinct reaction against the use of any literary English at all in the classroom, but now the pendulum has swung the other way ..." (Hill, 1994, p.7).

Currently, literature is considered as a promising tool for language learning purposes. Different genres of literature such as novel, drama, poetry, and short story, have been involved into language teaching environments in many different ways. Scholars in the field have proposed various advantages for the use of literature in EFL/ESL classes as: being authentic, increasing motivation, developing cultural/intercultural awareness and globalization, providing intensive/extensive reading practice, developing sociolinguistic/pragmatic knowledge, promoting grammar and vocabulary Knowledge, reinforcing language skills, increasing emotional intelligence (EQ), and fostering critical thinking (Khatib, Rezaei \& Derakhshan, 2011).

Among different literary texts, short stories have been of great concern by a number of researchers (Egan, 1995; Eren, 2004; Erkaya, 2005; Strodt-Lopez, 1996 etc). Short story is a work of prose fiction which is shorter than the short novel, more restricted in characters and situations (Chang, 2006). A short story is usually concerned with not more than a few effects, problems or themes. In terms of character development, generally, a single aspect of a character's personality undergoes change or is revealed as a result of some incidents, confrontation or conflict. Short stories seem to be the unique literary works can be used in language teaching due to their practical implementation, compact nature and readability in one sitting. They are not broad in scope and have a single effect on the readers (Alagözlü, 2011).

Short stories are neatly organized most of the time, and have common elements that lend themselves to an analysis (Alagözlü, 2011). This analysis can be visualized by graphic organizers which can be manipulated at all stages of teaching reading. Moreover, the use of graphic organizers make the students retrieve the information obtained quite easily, which will support and enhance learning.

In this study the researcher wants to investigate whether using graphic organizers after reading a short story can have any effect on incidental vocabulary learning of Iranian intermediate EFL learners.

To fulfill the purpose of this study, the following question was raised:

$\circ$ Does the use of graphic organizers have any significant impact on vocabulary learning of Iranian intermediate EFL learners?

In order to investigate the above mentioned research question, the following null hypothesis was formulated:

- Using graphic organizers has no significant impact on vocabulary learning of Iranian intermediate EFL learners. 


\section{BenEFITS OF Using SHORT StORIES}

Storytelling is a linguistic activity that is educative because it allows individuals to share their personal understanding with others, thereby creating negotiated transactions (Egan, 1995 \& 1999). Using stories can help developing critical thinking, self monitoring, strategic flexibility, and fruitful peer interaction (Strodt-Lopez, 1996). He listed some skills that students can promote through using short stories as follow:

$\circ$ Using a variety of linguistic and non-linguistic background knowledge in making inferences and supporting them;

o Analyzing the causes of differences in interpretation;

$\circ$ Challenging and disagreeing harmoniously in English

Erkaya (2005) asserted that through short stories, instructors can teach literary, cultural, and higher-order thinking aspects. However, Erkaya (2005) emphasized that before novice instructors attempt to use short stories in their EFL classes, they should understand the benefits of short stories and plan classes that meet the needs of their students.

Greene (1996) summarized a few characteristics of good stories as follow:

$\circ$ Having a single theme, clearly defined, so that the reader will not be confused when reading the story.

- Having a well-developed plot.

$\circ$ Having pleasing sounds and rhythm to be more attractive to the children or teenagers.

$\circ$ Having believable characters and representing qualities such as good, evil or beauty to make the story clear to the readers.

$\circ$ Being faithful to source materials

- Having dramatic appeal with a perfectly safe edge of fear and sadness

$\circ$ Being appropriateness for the listener; stories that are too hard for some age groups to understand could not be good stories to them.

However, Eren (2004) argued that there is no strict rule to determine the length of short-stories. It is the teacher's duty to choose a story short enough to handle within course hours. He believes that the shortness of the text is important because it makes the learners feel they can read, understand and finish something in English, and it will create a sense of achievement and self-confidence.

Hill (1994, p. 15) points out some other basic criteria to be kept in mind while choosing a literary text including:

$\circ$ the needs and abilities of the students

$\circ$ the linguistic and stylistic level of the text

o the amount of background information required for a true

Eren (2004) noted that before giving the short-story, the teacher should decide the readability of the text to see if the vocabulary and sentence structure of the short-story is suitable to the level of the students. As students will not understand these sentences and words, they will get bored and not read the work (Eren, 2004). He also adds teachers should choose a short-story with minimized cultural values and attitudes, and explain them before studying the work.

McKay (2001, p. 322) and Rivers (1968, p. 230) point out that students read and enjoy a text if the subject-matter of the text is relevant to their life experience and interests. To them teachers need not select the material from the canons of famous writers, rather they may use short-stories written for teenagers.

Regarding the authenticity of short stories, there are some controversies over the use of graded or simplified materials. Harmer (2001) asserts that simplified books can be used as extensive reading materials. He stated that "Such books succeed because the writers or adaptors work within specific lists of allowed words and grammar; this means that students at the appropriate level can read them with ease and confidence" (p. 210).

Eren (2004) believes that if one of the aims of using short-story in class is to give the students a feeling of achievement and self confidence, simplified or graded materials will not achieve it. This is because the students will be aware of the fact that the text they are reading is not written for native speakers, but for foreign language learners. Therefore, he recommends the use of authentic short-stories.

\section{USING STORY MAPS AS GRAPHIC ORGANIZERS}

A graphic organizer is a diagram or illustration of a written or oral statement. Examples include matrices, hierarchies, and continua (Alagözlü, 2011). By facilitating learning, graphic organizers help develop an understanding of a body of knowledge and explore new information and relationships. They are valuable in having students access prior knowledge and gather new knowledge and information.

Visual organizers can be applied as a pre-teaching and post-teaching strategy for the purpose of introducing or reinforcing the key concepts in a text and how they might be pertinent (Chang, 2006). Visual organizers suffice for organizing students processing of text in both reading and writing. Often these organizers are employed to provide structure to lectures to class discussion (Hill, 1994). Hill further expounds that the visual organizer is usually a teachergenerated cue. To use the visual organizer strategy, the teacher must outline the topic, the main ideas are to be explained, and the essential supporting details are developed. Once the text discussion has progressed over several days, it is advisable to ask students to construct their own organizers or accomplish partially constructed ones. This will allow more passionate student involvement in the learning process. The organizer will become more personalized and less 
abstract (Hill, 1994). Therefore, the role of EFL learners has changed from merely the receivers of concepts and information to the creators of visual organizers representing their own thinking processes.

Graphic organizers can help immeasurably in teachers' and students' communication needs (Chang, 2006). The various kinds of visuals have unique qualities that make each type the "right" one to use in certain language-learning contexts.

The structure of short stories is appropriate for a representation through graphic organizers which enable readers to see the various elements of a story graphically and explore visually how they work together. Demonstrating the story elements with graphic organizers might initiate a process of meta-textual thinking (Alagözlü, 2011).

A story map is considered as a kind of graphic organizer which includes "a visual aid that displays the chunks of information to be studied" (Crandall, Jaramillo, Olsen \& Peyton, 2002, p. 2). A story map will help students understand the components of the story. Crandall et al.

(2002) describe a story map as follows: "A story map is one example of a graphic organizer. A story map breaks down the components of a story- characters, setting, and dialogue in a series of events or conflicts leading to a resolution-into chunks of text that can help students organize and comprehend the events of the story" p. 2). Crandall et al. (2002) explain the advantages of using graphic organizers as follows:

Graphic organizers can help teachers clarify their instructional goals. Teachers can ask themselves what they want their students to learn and how they can display this information graphically to help their students connect ideas...Discussions might take place as students clarify the connections, clear up misconceptions, and come to consensus on the structure of the map (p. 2).

Using a story map, teacher may encourage his/her students to infer meaning from the text, and is able to develop students' reading and speaking skills (Eren, 2004).

\section{METHOD}

\section{A. Participants}

The participants of the study were 100 male and female Iranian intermediate EFL learners with the age range of 16 to 30 at an English institute in Karaj. 60 homogeneous learners; whose scores on the standardized language proficiency test was one standard deviation below and above the mean, participated in the study, and they were assigned to two groups of experimental and control.

\section{B. Instruments}

Two kinds of tests were utilized in this study:

1. The Test of English as a Foreign Language (TOEFL, 1995 version). This test was administered as a standardized measure to check the homogeneity of subjects in terms of language and also it was used as a criterion to validate teacher-made vocabulary test. This TOEFL test consists of 100 items of three sections of structure and written expressions (40 items), vocabulary (30 items) and reading comprehension (30 items). The reliability of the test, as calculated through KR - 21 measure of internal consistency was found to be $(0.88)$.

2. A teacher-made multiple-choice test of vocabulary, consisting of 38 items. The vocabulary items were taken from the short stories used in the study. This test was used and used as both the pretest and the posttest (within 25 minutes). The test was validated by the researcher using the TOEFL test.

\section{Procedure}

To accomplish the purpose of this study, the researcher carried out the following procedures:

At first a TOEFL test of 100 multiple choice items was administered to the learners in order to homogenize them. 60 students, whose scores was one standard deviation below and above the mean, were selected and divided into two groups. In order to control the teacher variable, both groups were taught by the same teacher. After that a pre-test of 38 multiple choice vocabulary items, was administered to both the experimental and control groups. The reliability of the test was calculated through KR-21 formula $(\mathrm{r}=0.76)$. Then an 8 -session course of instruction began. This course lasted for a month (two sessions per week). For the best use of the allocated time, the students in both groups had to read the text before the class meeting. In this study 8 short stories were used by the researcher, and each short story was practiced within 45 minute classroom period. The researcher tried to select short stories which seemed to be interesting to the learners and had enough length to be covered during the time limit of the class sessions. One sample of the short stories used by the researcher (Thank You ma'am by Langston Hughes) and its related story map is provided in the Appendices of this paper (Appendix A and Appendix B).

Before reading the text in class, in both groups, the teacher gave very brief information about the writer in order that the students could see the writer in the context of her/his time. After the information about the writer, as pre-reading activities, the teacher asked some questions about daily life of the students which are related to the subject matter of the short story. After the pre-reading activities, while reading the text in class, the students might find some sentences long or difficult to understand. In this case, the teacher helped the students, either by paraphrasing or acting out or drawing.

The difference between the procedures used for two groups was in the post reading step during which for the experimental group the teacher made use of a graphic organizer in the form of a story map. As explained earlier, "a 
story map breaks down the components of a story- characters, setting, and dialogue in a series of events or conflicts leading to a resolution-into chunks of text that can help students organize and comprehend the events of the story" (Crandall et al., 2002, p. 2). Using a story map, teacher encouraged her students to infer meaning from the text. Asking suitable questions the teacher helped students to fill the boxes in the organizer. So, the students have to infer answers to these questions from the work.

After reading the story the learners in the control group were given a set of factual questions, based on the story, whose answers could be find in the text. Then the answers to the questions were checked by the teacher and the points of disagreement were discussed by the learners.

At the end of the course, students in the control and experimental groups were given the 38 item vocabulary test the same as pre-test. To examine whether there was a statistically significant difference between the two groups, a t-test was run.

\section{Data AnAlysis}

After administration of the TOEFL test those participants who scored within the range of one standard deviation above and below the mean were selected for the main study. The results are illustrated in Table1.

TABLE 1.

DEACRIPTIVE STATISTICS FOR THE PROICIENCY TEST

\begin{tabular}{|l|l|l||l||}
\hline $\mathrm{N}$ & Mean & SD & Acceptable Range \\
\hline \hline 100 & 30.68 & 9.263 & {$[21.417-39.943]$} \\
\hline
\end{tabular}

After administering the pre-test, for the experimental group $(\mathrm{M}=14.36$ out of $40, \mathrm{SD}=3.89)$, and for the control group $(\mathrm{M}=12.59$ out of $40, \mathrm{SD}=4.37)$. Analyzing the data of the post-test showed that for the experimental group ( $\mathrm{M}$ $=30.66, \mathrm{SD}=3.26)$, and for the control group $(\mathrm{M}=20.67, \mathrm{SD}=4.54)$. Tables 2 and Table 3 represents the summarized data for the pre-test and post-test respectively.

TABLE 2.

SUMMARIZED DATA FOR THE PRE-TEST

\begin{tabular}{|l||l||l|}
\hline \multicolumn{2}{|c|}{ SUMMARIZED DATA FOR THE PRE-TEST } \\
\hline Statistical Data & Control Group & Experimental Group \\
\hline Number of Subjects & 30 & 30 \\
\hline Mean & 12.59 & 14.36 \\
\hline Variance & 19.10 & 15.14 \\
\hline SD & 4.37 & 3.89 \\
\hline
\end{tabular}

TABLE 3.

SUMMARISED DATA FOR THE POST-TEST

\begin{tabular}{|l||l||l|}
\hline Statistical Data & Control Group & Experimental Group \\
\hline Number of Subjects & 30 & 30 \\
\hline Mean & 20.67 & 30.66 \\
\hline Variance & 20.65 & 10.67 \\
\hline SD & 4.54 & 3.26 \\
\hline
\end{tabular}

The difference between the mean scores of the two groups shows that there has been a kind of difference between the performances of the two groups in learning vocabulary. In order to see whether this difference is statistically significant the researcher used the t-test formula.

\section{RESULTS AND DISCUSSION}

In order to test the hypothesis through $t$-test, first the homogeneity of the variances was checked through an $\mathrm{F}$ test. The value of $\mathrm{F}(58.60)=7.52>0.05$ was statistically significant. Therefore variances were not homogenous and the $t$ separate formula was used. By using this formula $t$ sep was calculated to be 4.38 . Then the two parameters of the $t$ observed and $t$-critical were compared. The results are illustrated in Table 4.

TABLE 4.

$T$-VALUES

\begin{tabular}{|l||l||l||l|}
\hline$t$-critical & Alpha level & Degree of freedom & $t$-observed \\
\hline 1.68 & 0.05 & 48 & 4.38 \\
\hline
\end{tabular}

As shown in the table above, the $t$-observed $=4.40, \mathrm{p}=0.05$ (one tailed), $\mathrm{d}=48$, and the $t$-critical $=1.65$. Thus the $t$ observed value was greater than the $t$-critical value meaning that there was a statistically significant difference between the performances of the two groups and subjects, who received vocabulary instruction through cooperative tasks, outperformed the control group.

The central question guiding the study was whether or not the use of story maps as advance organizers in the language classroom has any impact on vocabulary learning of Iranian EFL learners. Having done all the necessary data 
analysis, the results of the study provided support for the value of story maps as effective tools for incidental learning of vocabulary.

\section{CONCLUSION}

The story making elements in a short story like plot, characters, conflict, climax, and resolution can be easily recognized and demonstrated by graphic organizers, which are effective visual aids that arrange essential aspects of an idea or topic into a pattern using labels (Alagözlü, 2011).

Teaching short stories via graphic organizers make students to think of short stories as literary texts that are argumentative in nature. Each aspect of a short story (facts, relationships, properties, conflict, storyline plot, and characters) can be easily visualized through the use of graphic organizers. Graphic organizers help students recall the information in the text to be used for claims, arguments, evidence, and assumptions on which they will probably construct their reasoning (Alagözlü, 2011). According to him the use of graphic organizers in teaching short stories might be effectively used especially at post reading stage, once the story has been read and comprehended.

Incidental vocabulary learning occurs 'when the learners are required to perform a task involving the processing of some information without being told in advance that they will be tested afterwards on their recall of the information' (Laufer \& Hulstijn , 2001, p. 10).

Using story maps as graphic organizers for understanding short stories was found to be of great importance to enhance the learners' incidental vocabulary learning. By asking suitable questions the teacher helped students to fill the boxes in the organizer. So, the students have to infer answers to these questions from the short story. A story map helps students understand the components of the story more clearly by breaking down the components of a story- characters, setting, and dialogue in a series of events or conflicts. This will help students organize and comprehend the events of the story. In this way incidental learning of vocabulary occurs when the students focus on comprehending the text.

It seems that students in the experimental group get more involved in the story than the students in the control group. Learners in the control group can find the answers in the text without any deep understanding of the story. There are less opportunities for negotiation of meaning among them. On the other hand, in the experimental group learners need to understand the story more deeply in order to be able to fill in the organizer. Therefore, as the results of this study showed, greater amount of incidental learning of vocabulary occurred in the learners in the experimental group.

\section{APPENDIX (A)}

Thank You ma'am

By Langston Hughes

She was a large woman with a large purse that had everything in it but hammer and nails. It had a long strap, and she carried it slung across her shoulder. It was about eleven o'clock at night, and she was walking alone, when a boy ran up behind her and tried to snatch her purse. The strap broke with the single tug the boy gave it from behind. But the boy's weight and the weight of the purse combined caused him to lose his balance so, intsead of taking off full blast as he had hoped, the boy fell on his back on the sidewalk, and his legs flew up. the large woman simply turned around and kicked him right square in his blue-jeaned sitter. Then she reached down, picked the boy up by his shirt front, and shook him until his teeth rattled.

After that the woman said, "Pick up my pocketbook, boy, and give it here." She still held him. But she bent down enough to permit him to stoop and pick up her purse. Then she said, "Now ain't you ashamed of yourself?"

Firmly gripped by his shirt front, the boy said, "Yes'm."

The woman said, "What did you want to do it for?"

The boy said, "I didn't aim to."

She said, "You a lie!"

By that time two or three people passed, stopped, turned to look, and some stood watching.

"If I turn you loose, will you run?" asked the woman.

"Yes'm," said the boy.

"Then I won't turn you loose," said the woman. She did not release him.

"I'm very sorry, lady, I'm sorry," whispered the boy.

"Um-hum! And your face is dirty. I got a great mind to wash your face for you. Ain't you got nobody home to tell you to wash your face?"

"No'm," said the boy.

"Then it will get washed this evening," said the large woman starting up the street, dragging the frightened boy behind her.

He looked as if he were fourteen or fifteen, frail and willow-wild, in tennis shoes and blue jeans.

The woman said, "You ought to be my son. I would teach you right from wrong. Least I can do right now is to wash your face. Are you hungry?"

"No'm," said the being dragged boy. "I just want you to turn me loose."

"Was I bothering you when I turned that corner?" asked the woman. 
"No'm."

"But you put yourself in contact with me," said the woman. "If you think that that contact is not going to last awhile, you got another thought coming. When I get through with you, sir, you are going to remember Mrs. Luella Bates Washington Jones."

Sweat popped out on the boy's face and he began to struggle. Mrs. Jones stopped, jerked him around in front of her, put a half-nelson about his neck, and continued to drag him up the street. When she got to her door, she dragged the boy inside, down a hall, and into a large kitchenette-furnished room at the rear of the house. She switched on the light and left the door open. The boy could hear other roomers laughing and talking in the large house. Some of their doors were open, too, so he knew he and the woman were not alone. The woman still had him by the neck in the middle of her room.

She said, "What is your name?"

"Roger," answered the boy.

"Then, Roger, you go to that sink and wash your face," said the woman, whereupon she turned him loose-at last. Roger looked at the door-looked at the woman-looked at the door-and went to the sink.

Let the water run until it gets warm," she said. "Here's a clean towel."

"You gonna take me to jail?" asked the boy, bending over the sink.

"Not with that face, I would not take you anywhere," said the woman. "Here I am trying to get home to cook me a bite to eat and you snatch my pocketbook! Maybe, you ain't been to your supper either, late as it be. Have you?"

"There's nobody home at my house," said the boy.

"Then we'll eat," said the woman, "I believe you're hungry — or been hungry—-to try to snatch my pocketbook."

"I wanted a pair of blue suede shoes," said the boy.

"Well, you didn't have to snatch my pocketbook to get some suede shoes," said Mrs. Luella Bates Washington Jones. "You could of asked me."

"M'am?"

The water dripping from his face, the boy looked at her. There was a long pause. A very long pause. After he had dried his face and not knowing what else to do dried it again, the boy turned around, wondering what next. The door was open. He could make a dash for it down the hall. He could run, run, run, run, run!

The woman was sitting on the day-bed. After a while she said, "I were young once and I wanted things I could not get."

There was another long pause. The boy's mouth opened. Then he frowned, but not knowing he frowned.

The woman said, “Um-hum! You thought I was going to say but, didn't you? You thought I was going to say, but I didn't snatch people's pocketbooks. Well, I wasn't going to say that." Pause. Silence. "I have done things, too, which I would not tell you, son-neither tell God, if he didn't already know. So you set down while I fix us something to eat. You might run that comb through your hair so you will look presentable."

In another corner of the room behind a screen was a gas plate and an icebox. Mrs. Jones got up and went behind the screen. The woman did not watch the boy to see if he was going to run now, nor did she watch her purse which she left behind her on the day-bed. But the boy took care to sit on the far side of the room where he thought she could easily see him out of the corner of her eye, if she wanted to. He did not trust the woman not to trust him. And he did not want to be mistrusted now.

"Do you need somebody to go to the store," asked the boy, "maybe to get some milk or something?"

"Don't believe I do," said the woman, "unless you just want sweet milk yourself. I was going to make cocoa out of this canned milk I got here."

"That will be fine," said the boy.

She heated some lima beans and ham she had in the icebox, made the cocoa, and set the table. The woman did not ask the boy anything about where he lived, or his folks, or anything else that would embarrass him. Instead, as they ate, she told him about her job in a hotel beauty-shop that stayed open late, what the work was like, and how all kinds of women came in and out, blondes, red-heads, and Spanish. Then she cut him a half of her ten-cent cake.

"Eat some more, son," she said.

When they were finished eating she got up and said, "Now, here, take this ten dollars and buy yourself some blue suede shoes. And next time, do not make the mistake of latching onto my pocketbook nor nobody else's-because shoes come by devilish like that will burn your feet. I got to get my rest now. But I wish you would behave yourself, son, from here on in."

She led him down the hall to the front door and opened it. "Good-night! Behave yourself, boy!" she said, looking out into the street.

The boy wanted to say something else other than "Thank you, m'am" to Mrs. Luella Bates Washington Jones, but he couldn't do so as he turned at the barren stoop and looked back at the large woman in the door. He barely managed to say "Thank you" before she shut the door. And he never saw her again.

APPENDix (B) 
Story Map of Thank You ma’am by Langston Hughes (As cited in Alagözlü, 2011, p. 38)

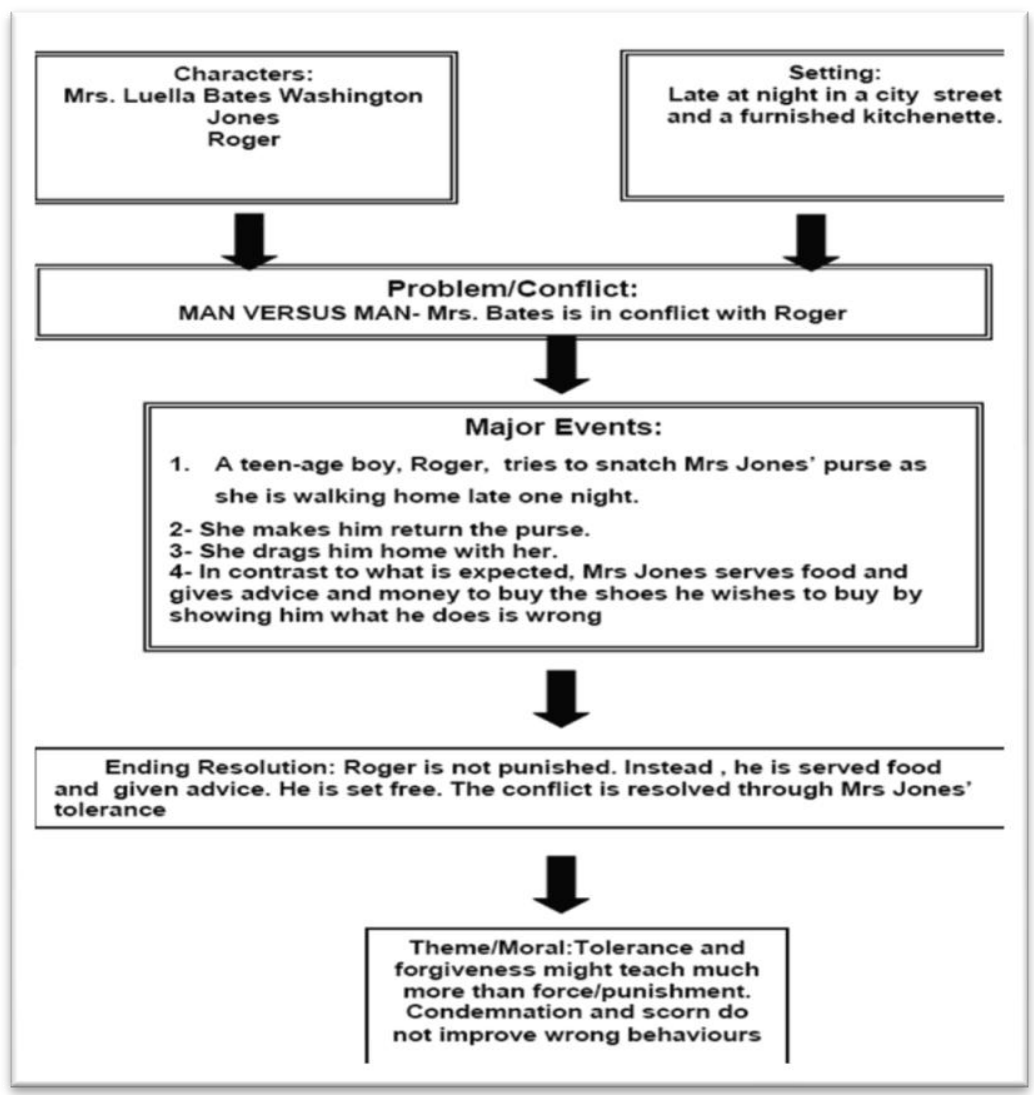

\section{REFERENCES}

[1] Alagözlü, N. (2011). Infusing graphic organizers and short stories in language teaching. Retrieved August 2011 from dergiler.ankara.edu.tr/dergiler/27/755/9626.pdf

[2] Chang, Y. (2006). Visual organizers as scaffolds in teaching English as a foreign language. Retrieved August 2011 from www.eric.ed.gov/ERICWebPortal/recordDetail?accno=ED494210

[3] Crandall, J., Jaramillo, A., Olsen, L., \& Peyton, J. K. (2002). Using cognitive strategies to develop English language and literacy. Retrieved July 2011 from www.cal.org/resources/digest/0205crandall.html

[4] Egan, K. (1995). Narrative and learning: A voyage of implications. In H. Mc Ewan \& K. Egan (Eds). Narrative in teaching, learning, and research. (pp.116-125). NY: Teachers College Press.

[5] Egan, K. (1999). Children's minds: Talking rabbits and clockwork oranges. NY: Teachers College Press.

[6] Eren, Z. (2004). The use of short story in teaching English to the students of public high schools. Hacettepe Universitesi Egitim Fakültesi Dergisi, 26, 41-47

[7] Erkaya, O. R. (2005). Benefits of using short stories in the EFL Context. Asian EFL Journal, 8, 1-13.

[8] Greene, E. (1996). Storytelling: Art and technique (3rd ed.). New Jersey: Bowker.

[9] Harmer, J. (2001). The practice of English language teaching. China: Pearson.

[10] Hill, J. (1994). Using literature in language teaching. London: Macmillan.

[11] Hughes, L. (1998). Thank You Ma'm. Retrieved August 2011 from http://ebookbrowse.com/gdoc.php?

[12] Khatib, M., Rezaei, S., Derakhshan, A. (2011). Literature in EFL/ESL Classroom. English Language Teaching Journal, 4(1), 201-208.

[13] Laufer, B., \& Hulstijn, J. (2001). Incidental vocabulary acquisition in a second language: The construct of task induced involvement. Applied Linguistics, 22(1), 1-26.

[14] McKay, S. (2001). Literature as content for ESL/EFL. In M. Celce-Murcia (Eds.), Teaching English as a second or foreign language (pp. 319-332) Boston: Heinle and Heinle.

[15] Paley, G. (1995). Samuel. Retrieved August 2011 from http://www2.selu.edu/Academics/Faculty/scraig/paley.html

[16] Rivers, W. (1968). Teaching foreign-language skill. Chicago: Cambridge University Press.

[17] Strodt-Lopez, B. (1996). Using stories to develop interpretive processes. ELT Journal, 50(1), 35- 42.

Mohammad Khatib is an Assistant Professor of TEFL at Allameh Tabataba'i University. He holds a Ph.D. in TEFL (Allameh Tabataba'i University, 1999), an M.A. and a B.A. in English Literature from Tehran University (1977 and 1972 respectively). He began teaching at Allameh in 1981 and presently offers graduate and post-graduate courses in SLA Theories, Methodology, 
Literature in EFL Classes, and English Literature. He began teaching at Allameh in 1981 and presently offers graduate and postgraduate courses in SLA Theories, Methodology, Literature in EFL Classes and English Literature. His main areas of interest include SLA Theories, language learning strategies, culture and the integration of language and literature. He has published some articles on TEFL in Iranian Journals of Applied Linguistics. He has translated a book of short stories from famous writers of the world and published a guidebook on Shakespeare's selected sonnets. E-mail address: mkhatib27@yahoo.com

Laleh Fakhraee Faruji was born in Quchan, Iran. She is a Ph.D candidate in TEFL at Islamic Azad University, Science and Research Branch, Tehran, Iran. She received her MA in TEFL from Islamic Azad University, North Tehran, Iran in 2008. She is also a faculty member of English department at Islamic Azad University, Shahr-e -Qods Branch, Tehran, Iran. Her recent publications include: "Forgetting vs. Remembering: Implications in Language Teaching', ELTWeekly, 2011, Issue 83, and "Connectionist Models: Implications in Second Language Acquisition" in BRAIN Journal (Broad Research in Artificial Intelligence and Neuroscience), Volume 2, Issue 3, September 2011. 